\title{
Fishes of the King Edward River in the Kimberley region, Western Australia
}

\author{
David L. Morgan \\ Freshwater Fish Group, Centre for Fish and Fisheries Research, Murdoch University, Murdoch, \\ Western Australia 6150, Australia. \\ E-mail: d.morgan@murdoch.edu.au
}

\begin{abstract}
The King Edward River, in the far north of the Kimberley region of Western Australia drains approximately $10,000 \mathrm{~km}^{2}$ and discharges into the Timor Sea near the town of Kalumburu. This study represents an ichthyological survey of the river's freshwaters and revealed that the number of freshwater fishes of the King Edward River is higher than has previously been recorded for a Western Australian river. Twenty-six strictly freshwater fish species were recorded, which is three species higher than the much larger Fitzroy River in the southern Kimberley. The study also identified a number of range extensions, including Butler's Grunter and Shovel-nosed Catfish to the west, and the Slender Gudgeon to the north and east. A possibly undescribed species of glassfish, that differs morphologically from described species in arrangement of head spines, fin rays, as well as relative body measurements, is reported. A considerable proportion of Jenkins' Grunter, which is widespread throughout the system but essentially restricted to main channel sites, had 'blubber-lips'. There were significant differences in the prevailing fish fauna of the different reaches of the King Edward River system. Thus fish associations in the upper King Edward River main channel were significantly different to those in the tributaries and the main channel of the Carson River. Similarly, the fauna of the Carson River, which was much more diverse than the King Edward River main channel and tributary sites, was characterised by many species that were not found in other parts of the river. The presence of natural barriers, such as waterfalls or rock bars do not permit upstream migrations of fishes and are considered to be the main factor in limiting the distribution of some species. For example, many species are restricted to the lower sections of the Carson River, and include Bony Bream, Lesser Salmon Catfish, Shovel-nosed Catfish, Black Catfish, False-spined Catfish, Freshwater Longtom, Prince Regent Hardyhead, Mouth Almighty, Barred Grunter and Butler's Grunter. It is hypothesised that these natural barriers were in place long before many of these latter species colonised the King Edward River. Some species tend to only be found within tributary sites, e.g. Kimberley Mogurnda, while others are most abundant in tributaries rather than main channel sites, e.g. Western Rainbowfish and Spangled Perch. Waterfalls are also seen as limiting the number of migratory marine/estuarine species that enter freshwaters. For example, only three species that require the marine/estuarine environment to complete their life-cycle were captured in the freshwaters of the King Edward River system. This compares to 14 species that utilise the freshwaters of the Fitzroy River.
\end{abstract}

\section{INTRODUCTION}

Due to the isolation and remoteness of the Kimberley region of northern Western Australia ichthyological surveys of the region's rivers did not commence until the mid-1970s. The region has a comparatively high diversity of fishes and inevitably, many of the original examinations of the region's freshwater fishes revealed undescribed species (see Allen 1975, 1978; Hutchins 1977, 1981; Vari 1978; Hoese and Allen 1983; Allen and Feinberg 1998; Morgan et al. 2004). Many of these newly discovered species are endemic to the Kimberley which has 17 endemic freshwater fishes and two endemic genera (see above and Allen et al. 2002), highlighting the importance of the region to Australia's aquatic biodiversity.

The waters of the King Edward and Carson Rivers converge approximately $15 \mathrm{~km}$ north of the Aboriginal community of Kalumburu in the northern Kimberley, before entering Napier Broome Bay (Figure 1). Previous published ichthyological surveys of the catchment are restricted to those by Hutchins (1977) and Allen and Leggett (1990). The 
sites sampled by Hutchins (1977) were all within the Drysdale National Park and included five sites on the Carson River, four sites on Palmoondoora Creek and three sites on Orchid Creek. Allen and Leggett (1990) sampled one site on the King Edward River, three sites on the Carson River and one site each on the Morgan River and Monger Creek. Hutchins (1977) reported 18 species from the Carson River within the Drysdale River National Park, while Hutchins (1981) tabulated a total of 11 species of freshwater fishes from the King Edward River and 20 species from the Carson River.

From the above it is evident that the previous ichthyological surveys of the King Edward and Carson rivers were not comprehensive but instead were limited to a small number of sites in specific areas (e.g. Drysdale River National Park). The main aim of the current study was to provide a broader examination of the catchment by examining the fishes of both the King Edward and Carson rivers and their tributaries. A secondary aim was to compare the fish faunal associations between the two major systems (i.e. King Edward River and Carson River) and their tributaries, testing the hypothesis that these very different major tributaries will have different faunas as a result of isolating mechanisms such as instream barriers, and that, as was the case for the more southerly Fitzroy River (see Morgan et al. 2004), differences will also be found when comparing smaller tributaries.

\section{MATERIALS AND METHODS}

\section{Study area}

The catchment of the King Edward and Carson rivers, in the Kimberley Basin, flow in a northerly direction and encompass approximately 10,000 $\mathrm{km}^{2}$ (Figure 1). The headwaters of the King Edward

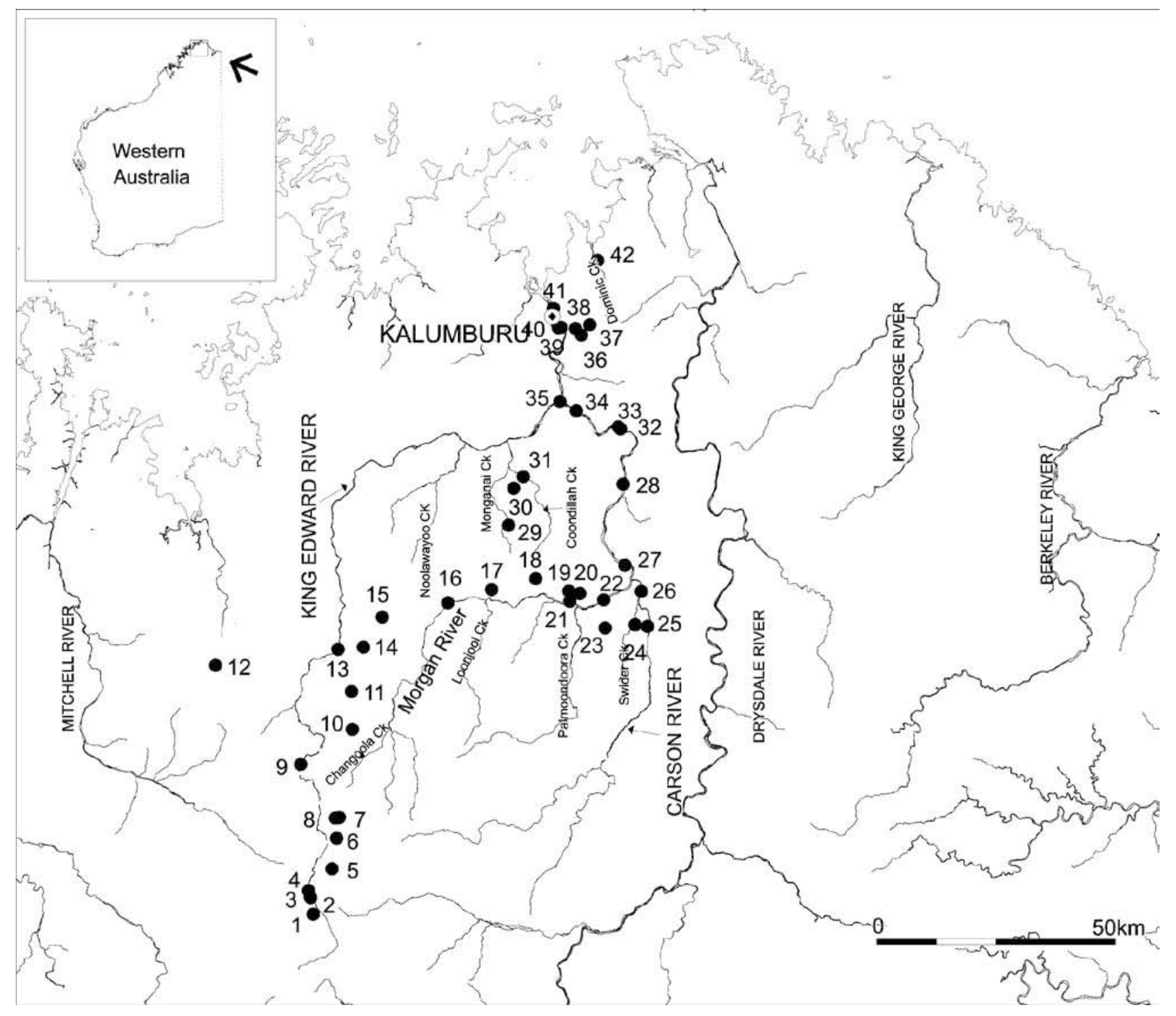

Figure 1 The sites sampled for fish in the King Edward and Carson River systems, Western Australia. 
River arise near the Gardner Plateau (King Leopold Sandstone; $500 \mathrm{~m} \mathrm{ASL}$ ) to the west of the Foster Range. Minor tributaries of the King Edward River include Noolawayoo Creek, Cole Creek, Mongonai Creek and Coondillah Creek. The Carson River has its headwaters in the Foster Range (365-440 $m$ ASL) and the main channel follows the Carson Escarpment (320-410 m ASL). The major tributaries of the Carson River incorporate the Morgan River and tributaries including Loonjool Creek and Palmoondoora Creek.

The climate of the region is monsoonal and is characterised by a hot wet summer that is followed by an extended warm dry season with little precipitation occurring between April and October (Vigilante et al. 2004). Rainfall in the region varies substantially from year to year and is often influenced by tropical cyclones. The mean annual rainfall is $>1200 \mathrm{~mm}$ at Kalumburu, near the mouth of the river, while Doongan Station in the headwaters receives, on average, $\sim 1100 \mathrm{~mm}$ (Bureau of Meteorology; Vigilante et al. 2004). The wet season extends from December to March with mean monthly rainfall being greatest in these months. On average, $\sim 80 \%$ of the annual rainfall for Doongan Station (annual mean rainfall $=1106.6$ $\mathrm{mm}$ ) and Kalumburu (annual mean rainfall = $1217.3 \mathrm{~mm}$ ) falls during this period. Conversely, between April and October the region receives little rainfall, with a combined average of less than 1.7 rainy days in each month during this period (Bureau of Meteorology). The King Edward River and its tributaries are exposed to high temperatures for most of the year with the mean monthly temperature for both Kalumburu and Doongan Station (near the source of the King Edward River) being, on average, $>30^{\circ} \mathrm{C}$ (Bureau of Meteorology). The hottest months, September to November, are immediately prior to the onset of the wet season where mean temperature is $\sim 36^{\circ} \mathrm{C}$.

\section{Fish sampling}

During two separate sampling trips, in October and November 2004 and in June and July 2005, 42 sites on the King Edward River and Carson River and their tributaries were sampled for fish (Figure 1; Table 1). This included one site on Dominic Creek that flows into Mission Cove in Napier Broome Bay and is not connected by freshwater to the King Edward River; noting that this site is not included in overall diversity of the river. Fish were captured using a variety of fine mesh seine nets, gill nets and line fishing and were observed using mask and snorkel, and from visual surveys along the bank or from the bow of a boat. The longitude and latitude were recorded at each site sampled. The maps of the sample sites and species distributions were created using the above GPS data and the program
MapInfo. Replicate water temperature $\left({ }^{\circ} \mathrm{C}\right)$ and conductivity $\left(\mu \mathrm{S} \mathrm{cm}{ }^{-1}\right.$ standardised to $25^{\circ} \mathrm{C}$ ) were measured in situ at each sampling occasion with a YSI portable conductivity meter. Rainfall and temperature data were sourced from the Bureau of Meteorology.

\section{Fish identification and systematics}

On capture, fish were identified and the majority released immediately. Occasionally it was necessary to preserve specimens for formal identifications. This was the case for a number of the ambassids (glassfish) and eleotrids (gudgeons) captured. Fish were also kept for live photography. In this paper, the species phylogenetic order follows Nelson (1994). The glassfish are referred to as Ambassidae rather than Chandidae (cf. Allen and Burgess 1990; Pusey et al. 2004) since Eschmeyer (2004) notes that the former has precedence over the latter. Kluzinger (1870) was the first to use the name Ambassidae, earlier than Fowler (1905), who was the first to use Chandidae. In some cases there was a need to verify species identifications from the field. The Ambassidae collected, where possible, were identified from Allen and Burgess (1990), Mogurnda species from Allen and Jenkins (1996), Hypseleotris species from Hoese and Allen (1983), Melanotaeniidae from Allen (1978) and Terapontidae from Vari (1978). For the purpose of this paper, freshwater species are considered to be those that are either obligate freshwater fishes or are capable of completing their life within the freshwater environment. Marine species are deemed those that must complete part of their life-cycle within the marine environment but may spend much of their life in freshwater, for example Barramundi (Lates calcarifer) breed in the estuary but may spend extended periods in freshwater habitats. Species such as the Lesser Salmon Catfish (Neoarius graeffei), Flathead Goby (Glossogobius giuris), Seven-spot Archerfish (Toxotes chatareus) and Empire Gudgeon (Hypseleotris compressa) are capable of breeding in both fresh and salt water (see Allen et al. 2002; Morgan et al. 2004) and have been considered freshwater species.

\section{Classifying the different regions of the King Edward River}

In order to determine if different fish fauna are associated with the different regions of the King Edward River system, the sample sites (see Figure 1), based on fish species abundance at each site, were categorised as either (1) upper main channel King Edward River, (2) main channel Carson River (including lower Morgan River downstream of, but including the waterfall at site 21), (3) King Edward tributary, (4) Carson River tributary sites (includes tributaries downstream of the confluence 


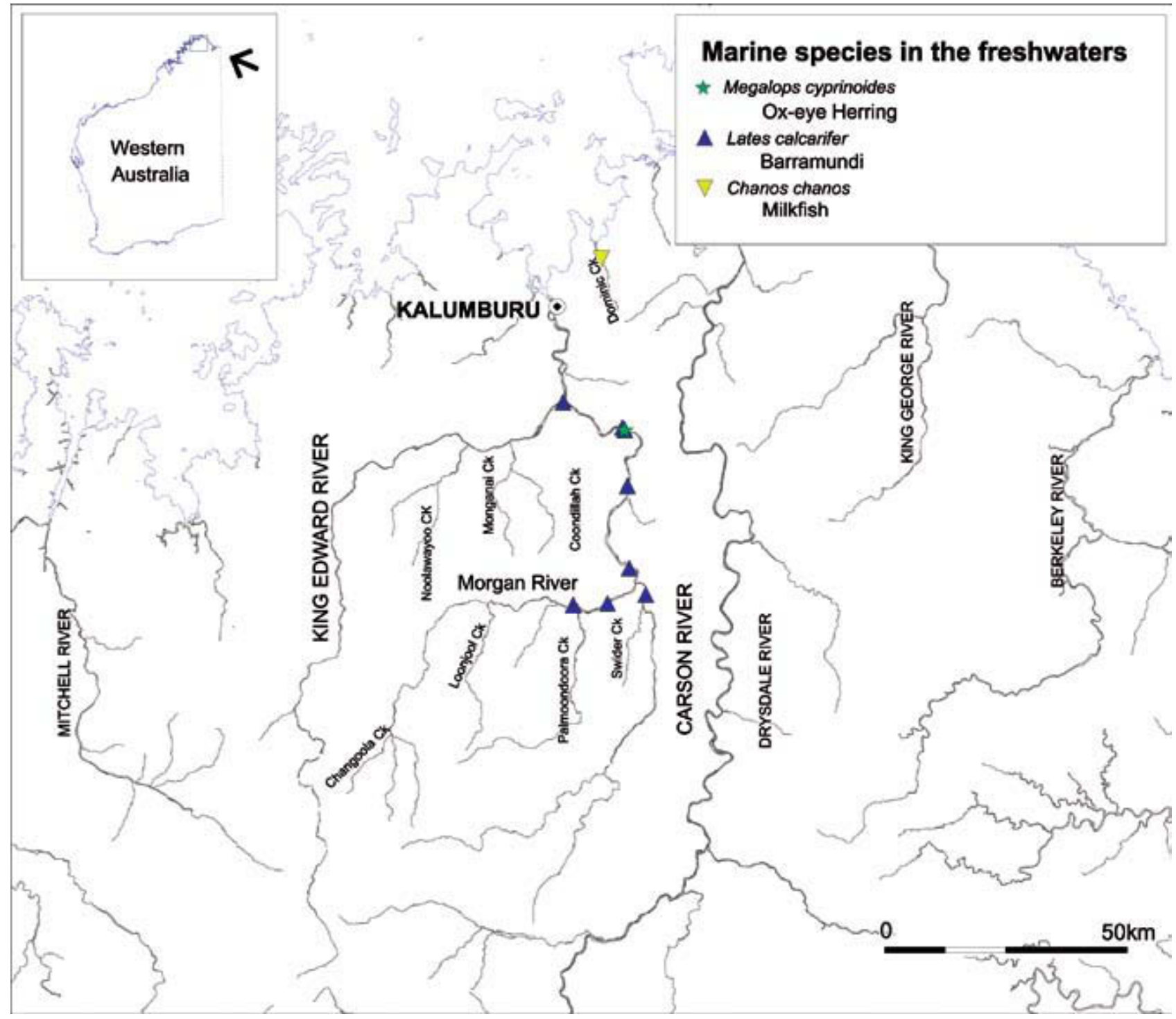

Figure 2 Locations of the marine/estuarine species that were captured in the freshwaters of the King Edward River system during this study.

with the King Edward River) or (5) Morgan River tributary sites (includes the Morgan River main channel upstream of the waterfall at site 21) (see Figure 1). The King Edward River included sites 1-4, 9, 13; tributaries of the King Edward River included sites 5-8, 12, 14-15, 29-31; the Morgan River included sites 10-11, 16-20; the Carson River included sites 21, 22, 25-28, 32-35; and the Carson River tributaries sites were 23, 24 and 36-41 (Figure 1; Table 1). Site 42 (Dominic Creek) was not included in analysis as it is outside of the main catchment and is discussed separately.

In order to test the hypothesis that the fish faunal composition would vary between these broad habitat types the sample sites were $a$ priori allocated to one of these categories and their fish community compared using one-way analysis of similarity (ANOSIM) in PRIMER (Clarke and Gorley 2001). In order to test for differences in community structure, a data set of the abundance of the different species captured in the 41 sites sampled in the catchment was used to construct a similarity matrix employing the Bray-Curtis similarity coefficient in the PRIMER package (Clarke and Gorley 2001).

The abundance data for the individual species captured at the different sample sites were square root transformed, and were used to construct a similarity matrix using the BrayCurtis similarity coefficient. One-way analysis of similarity (ANOSIM) was used to determine whether differences between the main sample site groups (1-5) (see above) were significant. Analysis of similarity generates an $R$-statistic that is an estimate of the similarity of the replicates within predetermined groups compared to similarities between groups; $R$ value of 1 indicates that all replicates within groups are more similar to one 
another than they are to any replicate in other groups whilst an $R$ value of 0 indicates that similarities within and between groups are the same on average. The similarity matrix that was generated was then ordinated and classified using non-metric multidimensional scaling (MDS) and hierarchical agglomerative cluster analysis in the PRIMER package (Clarke and Gorley 2001).

\section{Community contact}

Community organisations, including the Kimberley Land Council and Kimberley Language Resource Centre, were contacted to gain permission to do the work and ascertain what language groups and traditional owners might want to be involved. The Kalumburu Council, Kupungari Aboriginal Corporation and Wunambal-Gaambera Aboriginal Corporation (WGAC) were contacted prior to the commencement of fieldwork in 2004. Field research goals were outlined (including how the research would take place) as were the benefits that the research may have for the community, including the production of fish posters with language names. This survey work involved visiting sites in the King Edward and Carson River catchment areas that lay in Kwini or Ngarinyin country.

\section{RESULTS}

\section{The environment of the King Edward River}

Water temperatures at the sites sampled directly corresponded to the temperature regime to which they were exposed, with higher temperatures recorded in sites sampled during October and November as opposed to those sampled in June and July. Mean water temperatures ranged from $\sim 28-32^{\circ} \mathrm{C}$ in the October-November sampling period and from $\sim 23-27^{\circ} \mathrm{C}$ in the cooler June-July period. The highest mean water temperatures were recorded from the Carson River sites, with the highest mean water temperature for one Carson River site being $33.8^{\circ} \mathrm{C}$.

Conductivities of all sites sampled were generally very low $\left(<450 \mu \mathrm{Scm}^{-1}\right)$, with the upper King Edward River main channel sites having a mean conductivity of only $57.6 \mu \mathrm{Scm}^{-}$ ${ }^{1}$. Conductivities were generally highest in the tributary sites sampled. In terms of changes in conductivity during the different seasons, they were marginally higher in the October-November period, presumably as a result of a longer exposure to evaporation.

\section{Fish species captured}

A total of 14,304 fish from 29 fish species were captured or observed in the freshwaters of the King Edward River system during this study, including two species only recorded from Dominic Creek (site 42) (see Figure 1; Table 1). A further two species were reported by Hutchins (1977). Of the total of 31 species, 28 were considered to be freshwater species, while the remaining three species, i.e. Barramundi, Ox-eye Herring (Megalops cyprinoides) and Milkfish (Chanos chanos) are estuarine or marine species that may spend part of their life in freshwater. The marine species contributed to less than $0.15 \%$ ( 21 individuals) of the total catch and were only recorded from the main channel of the Carson River and from the Morgan River below the waterfall at site 21 (see Figures 1 and 2). This includes, however, a single Milkfish that was recorded from Dominic Creek (site 42) that is not part of the King Edward River system (see Figures 1 and 2).

In contrast to the low diversity of marine/ estuarine fishes captured in the freshwaters of the King Edward River system, the freshwater species diversity was high (Table 1). The Western Rainbowfish (Melanotaenia australis) accounted for over two-thirds of all fish captured and was found at 35 of the 42 sites sampled. The next most abundant species, the Spangled Perch (Leiopotherapon unicolor), was also encountered at 35 sites and contributed to $\sim 5.9 \%$ (828 individuals) of the total captures. The other freshwater species captured included some species not previously recorded from the river, i.e. Slender Gudgeon (Hypseleotris ejuncida), Kimberley Mogurnda (Mogurnda oligolepis), Silver Cobbler (Neoarius midgleyi), Rendahl's Catfish (Porochilus rendahli) and Butler's Grunter (Syncomistes butleri) and potentially a new species of glassfish (Ambassis sp. 1). A brief account of each of the freshwater species captured is given below.

\section{Species synopses}

\section{Bony Bream (Nematalosa erebi (Günther, 1868) (CLUPEIDAE)}

A total of 341 Bony Bream was captured at a total of nine sites during this study, all either within the Carson River or below the waterfall on the Morgan River (site 21) (Figure 3). None was captured in the King Edward River upstream of the confluence with the Carson River. Hutchins (1977) recorded five individuals from Palmoondoora Creek and 25 from the Carson River.

Lesser Salmon Catfish (Neoarius graeffei (Kner and Steindachner, 1867)) (ARIIDAE)

A total of 76 Lesser Salmon Catfish was captured during this study at seven sites. All capture sites were within the Carson River main channel or the lower reaches of the Morgan River downstream of site 21 (Figure 3). Hutchins (1977) also reports 
Table 1 The sites at which the different freshwater fish species were captured in the King Edward River and its tributaries and in the Carson River and tributaries including the Morgan River (see Figure 1 for site localities). ${ }^{+}$denotes that the species was reported by Hutchins (1977), ${ }^{\ddagger}$ by Allen and Leggett (1990) and ${ }^{\mathrm{D}}$ represents the species being only found in Dominic Creek (site 42). KE = King Edward, CR = Carson River.

\begin{tabular}{|c|c|c|c|}
\hline Fish species captured & $\begin{array}{l}\text { King Edward } \\
\text { River sites }\end{array}$ & Carson River sites & $\begin{array}{c}\text { Total } \\
\text { (KE,CR) }\end{array}$ \\
\hline \multicolumn{4}{|l|}{ Freshwater fishes } \\
\hline Bony Bream (Nematalosa erebi) & & $21,25-26,28,32-35,40^{+}$ & 0,9 \\
\hline Lesser Salmon Catfish (Neoarius graeffei) & & $21,25,26,28,32-35^{+}$ & 0,8 \\
\hline Shovel-nosed Catfish (Neoarius midgleyi) & & $21,22,26-28,32,35$ & 0,7 \\
\hline Black Catfish (Neosilurus ater) & & $21,28,32,34,35^{+}$ & 0,5 \\
\hline Hyrtl's Tandan (Neosilurus hyrtlii) & $1-3,7,8,13-15$ & $10,11,17,26,28,32,34,35^{+}$ & 8,8 \\
\hline False-spined Catfish (Neosilurus pseudospinosus) & & $28^{+}$ & 0,1 \\
\hline Rendahl's Catfish (Porochilus rendahli) & 1 & 40 & 1,1 \\
\hline Freshwater Longtom (Strongylura krefftii) & & $21,25-32,34,35^{+}$ & 0,11 \\
\hline Western Rainbowfish (Melanotaenia australis) & $1-9,13-15,29-31^{\ddagger}$ & $10,11,16,17,19-26,28,32,34,35,38-41^{+\ddagger}$ & 15,20 \\
\hline Slender Rainbowfish (Melanotaenia gracilis) & & $18^{+}$ & 0,1 \\
\hline Black-banded Rainbowfish (Melanotaenia nigrans) ${ }^{\mathrm{D}}$ & & & $\mathrm{D}$ \\
\hline Prince Regent Hardyhead (Craterocephalus lentiginosus) & & $21,22,28,32-35,38,40^{\ddagger}$ & 0,9 \\
\hline Macleay's Glassfish (Ambassis macleayi) & & $26,28,32-34^{\dagger \ddagger}$ & 0,5 \\
\hline Ambassis sp.1 & $1-6,9,13,14$ & $11,17,34,23,38,40$ & 9,6 \\
\hline Mouth Almighty (Glossamia aprion) & & $32,34,38,40^{\ddagger}$ & 0,4 \\
\hline Seven-spot Archerfish (Toxotes chatareus) & & $21,22,25-28,32-35,38^{+}$ & 0,11 \\
\hline Barred Grunter (Amniataba percoides) & & $19,21,22,24-28,32-35,38,40^{\dagger \ddagger}$ & 0,14 \\
\hline Long-nose Sooty Grunter (Hephaestus epirrhinos) & & + & 0 \\
\hline Jenkins' Grunter or Black Bream (Hephaestus jenkinsi) & $1-4,9,13,31$ & $16,17,19,21,22,25-28,32-35^{\ddagger \ddagger}$ & 7,13 \\
\hline Spangled Perch (Leiopotherapon unicolor) & $1-9,13-15,29-31^{\ddagger}$ & $10,16-20,21-26,28,32-36,38,40^{\dagger \ddagger}$ & 15,20 \\
\hline Butler's Grunter (Syncomistes butleri) & & $21,22,28,32,35$ & 0,5 \\
\hline Long-nose Grunter (Syncomistes trigonicus) & $3,9,13$ & $16,17,33^{+}$ & 4,3 \\
\hline Empire Gudgeon (Hypseleotris compressa) & & 41 & 0,1 \\
\hline Slender Gudgeon (Hypseleotris ejuncida) & & 32,34 & 0,2 \\
\hline Kimberley Mogurnda (Mogurnda oligolepis) & $7,8,14,15,29,30$ & $10,17,24,38$ & 6,4 \\
\hline Northern Trout Gudgeon (Mogurnda mogurnda) & & tł & 0 \\
\hline Giant Gudgeon (Oxyeleotris selheimi) & & $24^{\dagger \ddagger}$ & 0,1 \\
\hline Flathead Goby (Glossogobius giuris) & 3 & $21,26,28,32-35^{\dagger \ddagger}$ & 1,7 \\
\hline \multicolumn{4}{|l|}{ Marine fishes in the freshwaters } \\
\hline Ox-eye Herring (Megalops cyprinoides) & & 32 & 0,1 \\
\hline Milkfish (Chanos chanos) ${ }^{\mathrm{D}}$ & & & $\mathrm{D}$ \\
\hline Barramundi (Lates calcarifer) & & $21,22,26-28,32-33,35$ & 0,8 \\
\hline
\end{tabular}


this species from the Carson River upstream of the Morgan River mouth.

Shovel-nosed Catfish (Neoarius midgleyi (Kailola and Pierce, 1988)) (ARIIDAE)

A total of 131 Shovel-nosed Catfish (or Silver Cobbler) was captured during this study at seven sites (Figure 3). All capture sites were within the Carson River main channel or the lower reaches of the Morgan River downstream of site 21 (see Figure 3) and essentially parallels the distribution of the other fork-tailed catfish (Lesser Salmon Catfish) in the system. There have been no other published reports of this species being found in the catchment. The Western Australian Museum has a number of specimens from the Ord River system in WA, which is east of the Carson River, and one specimen from an undisclosed site that falls within the Fitzroy catchment. Allen et al. (2002) reports the species to be found in rivers east (and north) of the Fitzroy River in the southern Kimberley, however, recent studies have not recorded the species in that river (see Morgan et al. 2004). Thus, the finding of Silver Cobbler within the Carson River represents a notable range extension to the west by $\sim 200 \mathrm{~km}$. Fish up to $722 \mathrm{~mm}$ total length (TL) were captured during this study.

Black Catfish (Neosilurus ater (Perugia, 1894)) (PLOTOSIDAE)

As with the two fork-tailed catfishes, the eeltailed Black Catfish was only captured within the Carson River (Figure 3). The Black Catfish was much rarer that the fork-tailed catfishes with only nine individuals recorded at five sites. Highly regarded as a food fish to the people of Kalumburu, the nine captured during this study ranged from 314-402 mm TL. Hutchins (1977) also reported a single specimen from the Carson River upstream of the Morgan River mouth.

Hyrtl's Tandan (Neosilurus hyrtlii Steindachner, 1867) (PLOTOSIDAE)

Hyrtl's Tandan was widely distributed throughout the sites sampled in this study (see Figure 3). However, they were most abundant in the upper King Edward River main channel and its tributaries. For example, 65 individuals were found in four main channel sites and 175 in four tributary sites of the King Edward River. This contrasts the catches in the Carson River and Morgan River where only five and six individuals respectively were captured. None was captured in the Carson River tributary sites.

False-spined Catfish (Neosilurus pseudospinosus Allen and Feinberg, 1998) (PLOTOSIDAE)

A single False-spined Catfish (295 mm TL) was captured at site 28 in the Carson River during this study (see Figure 3). Hutchins (1977) reported 16 individuals from the Carson River (74-279 mm SL) and a further five specimens from Palmoondoora Creek (89-147 mm SL).

Rendahl's Catfish (Porochilus rendahli Whitley, 1928) (PLOTOSIDAE)

Rendahl's Catfish has not previously been reported from the King Edward or Carson Rivers. The species has a patchy distribution across northern Australia (Allen et al. 2002) and the same may be said within the King Edward River system (see Figure 3) where only two individuals were found at one site in the upper reaches of the King Edward River (site 1) and in one tributary site near the mouth of the river (site 40).

Freshwater Longtom (Strongylura krefftii (Günther, 1866)) (BELONIDAE)

A total of 41 Freshwater Longtom were recorded during this study, all of which were found either within the main channel of the Carson River or in the lower Morgan River (Figure 3). None was captured in the King Edward River upstream of the confluence with the Carson River. Hutchins (1977) recorded five individuals (61-329 $\mathrm{mm} \mathrm{TL}$ ) from the Carson River upstream of the junction with Orchid Creek.

Western Rainbowfish (Melanotaenia australis (Castelnau, 1875)) (MELANOTAENIIDAE)

The Western Rainbowfish was extremely widespread and abundant (Figure 3) and was captured at all main channel sites in the King Edward River and in all of the King Edward River tributary sites. The species was also found within all but one Morgan River site, where it was replaced by the Slender Rainbowfish, and all but two Carson River main channel sites and two Carson River tributary sites. Western Rainbowfish represented approximately $80 \%$ of all captures in the King Edward main channel, King Edward tributaries and Carson tributary sites, but it was much less abundant in the Carson River main channel (Figures 7 and 8).

Slender Rainbowfish (Melanotaenia gracilis Allen, 1978) (MELANOTAENIIDAE)

In contrast to the Western Rainbowfish, the Slender Rainbowfish is extremely restricted within the study region (Figure 3) and was only captured at a single tributary site within the Morgan River (site 3). At this site it was however very abundant, with 265 individuals captured. The only co-occurring species at this site was the Spangled Perch. The overall distribution of the Slender Rainbowfish is highly restricted, with it being known only to occur 
Table 2 Meristics and morphological counts for the unidentified glassfish captured in the King Edward River ( $\mathrm{n}=$ 10) compared to the Northwest Glassfish (Ambassis sp. - formerly Ambassis mulleri) (from Allen and Burgess 1990). For an explanation of characters see Allen and Burgess (1990). SL = standard length.

\begin{tabular}{lcc}
\hline Meristics and morphological counts & Northwest Glassfish & King Edward Glassfish \\
\hline Preorbital ridge & smooth or 1-11 spines & smooth \\
Suborbital & occasionally smooth or 1-14 spines & smooth \\
Supraorbital ridge & 1 spine & Smooth \\
Hind margin of preoperculum & $1-10$ spines & $9-12$ \\
Predorsal scales & $13-14$ & $23-26$ \\
Vertical scale rows & $25-26$ & $6-8$ \\
$1^{\text {st }}$ dorsal spines & 7 & $7-9$ \\
$2^{\text {nd }}$ dorsal soft rays & $8-9$ & $10-12$ \\
Pectoral fin rays & $11-13$ & $6.5-10.3$ \\
Snout length (\% of SL) & $6.3-8.1$ & $29.1-39.0$ \\
Body depth (\% of SL) & $36.4-45$ & $13.2-21.6$ \\
Caudal peduncle depth (\% of SL) & $15.5-17.5$ & $20.2-27.3$ \\
$1^{\text {st }}$ dorsal height (\% of SL) & $24-36.8$ & $15-16$ \\
Gill rakers on lower limb of first arch & $16-19$ & s. \\
\hline
\end{tabular}

in the King Edward and Drysdale River systems (Allen 1978; Allen et al. 2002).

Black-banded Rainbowfish (Melanotaenia nigrans Richardson, 1843) (MELANOTAENIIDAE)

The Black-banded Rainbowfish was not captured within the King Edward River system but it was found at a single site on Dominic Creek (site 42) which is $\sim 15 \mathrm{~km}$ to the east of the mouth of the King Edward River (Figure 3). The species was previously reported in Dominic Creek by Allen and Leggett (1990).

Prince Regent Hardyhead (Craterocephalus lentiginosus Ivantsoff, Crowley and Allen, 1987) (ATHERINIDAE)

The Prince Regent Hardyhead was absent from our catches in the King Edward River main channel and the tributary sites of the King Edward River and Morgan River (upstream of site 21; Figure 3), but was relatively abundant in the main channel of the Carson River and lower Morgan River and within two tributaries of the lower main channel (see Figures 3, 7 and 8). A total of 361 individuals were captured, with over $80 \%$ of these being found in the Carson River main channel and lower Morgan River. Allen and Leggett (1990) captured eight specimens of this species near Kalumburu.

Macleay's Glassfish (Ambassis macleayi (Castelnau, 1878)) (AMBASSIDAE)

Macleay's Glassfish was only captured within main channel sites of the Carson River (Figure 4). A total of 165 individuals were captured within five sites (see Figures 6 and 7). Allen and Leggett (1990) however, reported four individuals (16-26 mm SL) from Monger Creek, $\sim 10 \mathrm{~km}$ west of Kalumburu.

\section{Ambassis sp. (AMBASSIDAE)}

An unidentifiable species of glassfish (Ambassis sp.) was found to be widespread throughout the King Edward River system (Figure 3). It was particularly abundant in the main channel of the upper King Edward River where it was recorded at all sites (344 individuals). A further 110 individuals were captured within the tributaries of the upper King Edward, while 69, 22 and 57 were recorded from the Morgan River, Carson River and Carson tributaries, respectively. This species was not reported by previous authors from the river. Allen et al. (2002) provide a broad Kimberley distribution for the Northwest Glassfish (Ambassis sp., formerly A. mulleri), but based on the description they provide and from that in Allen and Burgess (1990), the King Edward glassfish can be distinguished by a number of characters. For example, from 10 individuals examined (22.5-49.9 mm TL; 17.1-36.6 mm SL), morphological differences such as head spines, fin rays, as well as relative body measurements are different (see Table 2). The suborbital, preorbital ridge and hind margin of the preoperculum are all smooth in the King Edward glassfish but are spinous on the Northwest Glassfish. Furthermore, there are differences in proportional body measurements and generally fewer gill rakers and predorsal scales in the King Edward Ambassis (Table 2). From the above it appears likely that the King Edward species may 

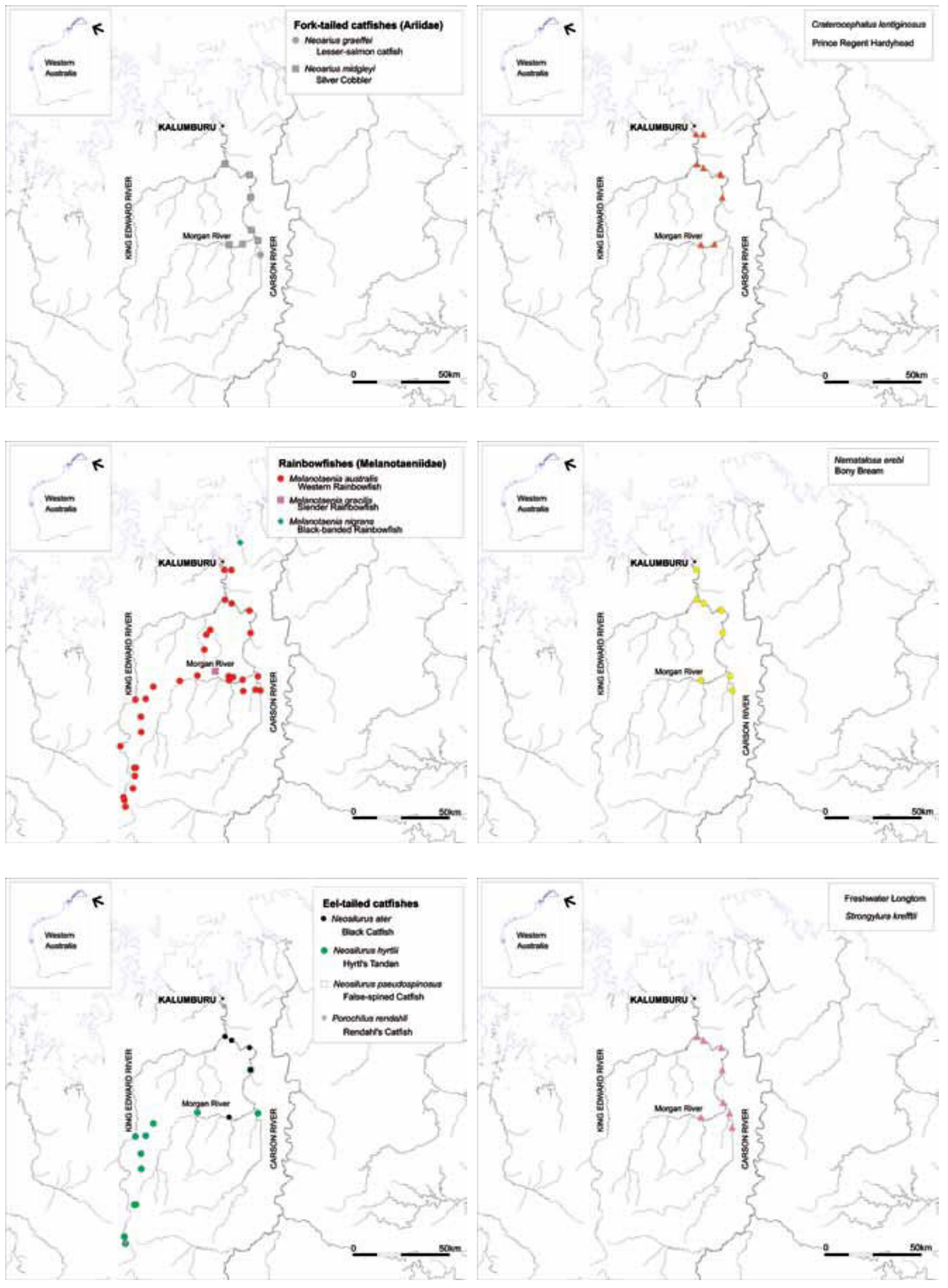

Figure 3 The distributions of, N. graeffei, N. midgleyi, C. lentiginosus, M. australis, M. gracilis, M. nigrans, N. erebi, N. ater, N. hyrtlii, N. pseudospinosus, P. rendahli and S. krefftii in the King Edward River system. 

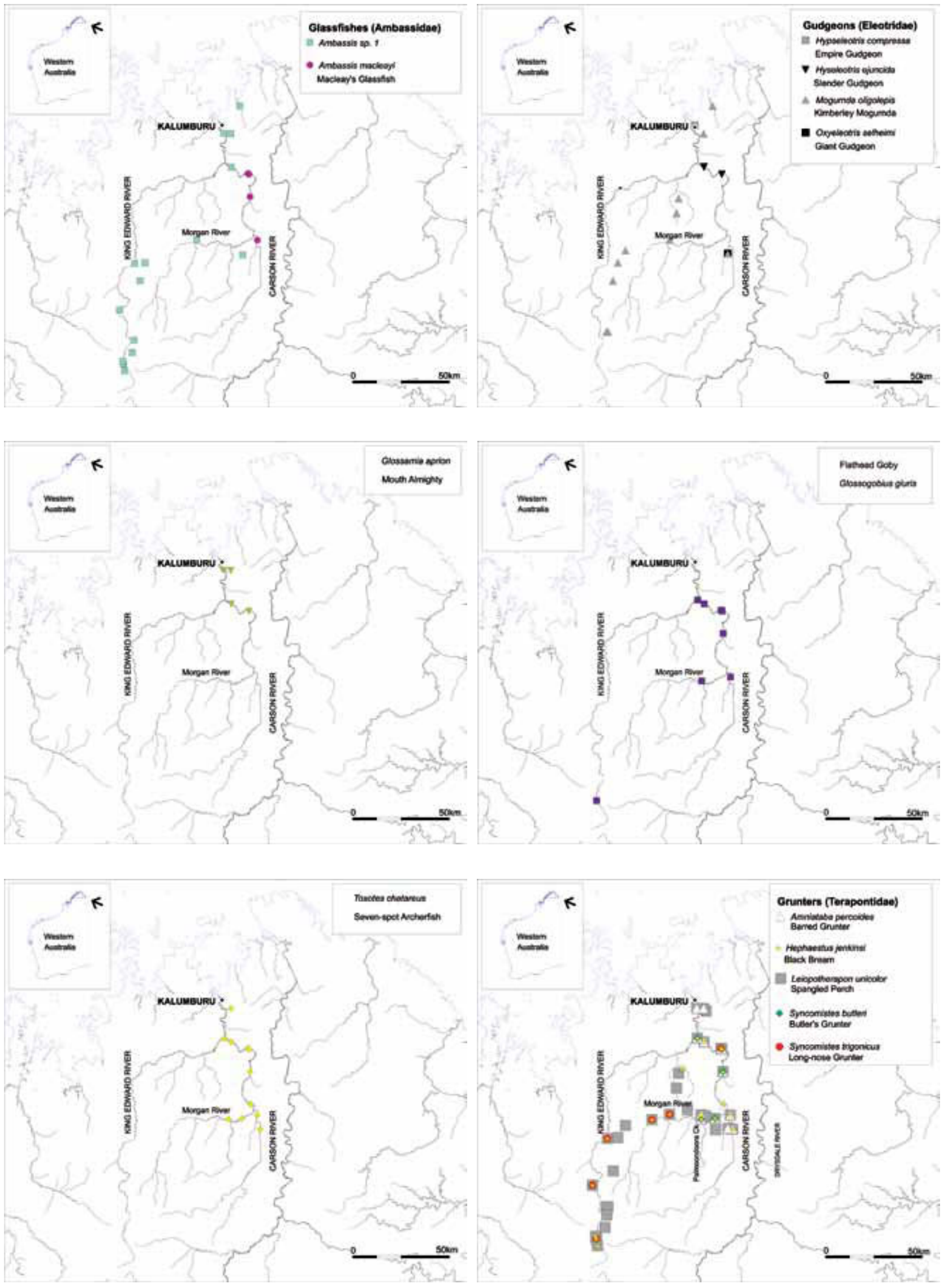

Figure 4 The distributions of, Ambassis sp., A. macleayi, H. compressa, H. ejuncida, M. oligolepis, O. selheimi, G. aprion, G. giuris, T. chatareus, A. percoides, H. jenkinsi, L. unicolor, S. butleri and S. trigonicus in the King Edward River system (N.B. Hutchins (1977) recorded H. epirrihinos (Terapontidae) from Palmoondoora Creek). 
be a new species. More detailed measurements of the specimens and comparisons of other taxa are required for its formal description.

Mouth Almighty (Glossamia aprion (Richardson, 1842)) (APOGONIDAE)

The Mouth Almighty was only captured at two main channel and two tributary sites of the Carson River (Figure 4). None was captured within the King Edward River. A total of 48 individuals were caught accounting for less than $0.4 \%$ of all fish captured. Allen and Leggett (1990) recorded five individuals from Monger Creek, $10 \mathrm{~km}$ west of Kalumburu, while Hutchins (1977) recorded five from the Carson River upstream of the confluence with the Morgan River.

Seven-spot Archerfish (Toxotes chatareus (Hamilton, 1822)) (TOXOTIDAE)

While Hutchins (1977) captured 12 specimens of the Seven-spot Archerfish in the Carson River above the confluence with the Morgan River, during this study a total of 363 individuals were recorded from all main channel Carson River sites sampled and from one tributary site (Figure 4). The species was not captured within the King Edward River upstream of the confluence with the Carson River, but accounted for $\sim 13 \%$ of all fish captured in the Carson River main channel and less than $1 \%$ of fish captured in the tributaries of the Carson River.

Barred Grunter (Amniataba percoides (Günther, 1864))

\section{(TERAPONTIDAE)}

The Barred Grunter was extremely common within the Carson River main channel, and with the exception of five individuals captured in the Carson tributaries it was not recorded anywhere else (Figure 4). A total of 360 individuals were recorded and they accounted for approximately $13 \%$ of all fish captured in the Carson River main channel. Allen and Leggett (1990) recorded three fish in Monger Creek and a further nine in the lower King Edward River near Monger Creek. Hutchins (1977) recorded a total of 26 individual Barred Grunter in the Carson River upstream of the confluence with the Morgan River and in Palmoondoora Creek below Morgan Falls.

Long-nose Sooty Grunter (Hephaestus epirrhinos Vari and Hutchins, 1978) (TERAPONTIDAE)

The Long-nose Sooty Grunter was not captured during this study but it was recorded by Hutchins (1977) below Morgan Falls on Palmoondoora Creek. Other than that record, the species is only known from the nearby Drysdale River (Figure 4).

Jenkins' Grunter (Hephaestus jenkinsi (Whitley, 1945)) (TERAPONTIDAE)

With the exception of two individuals captured in a small tributary of the King Edward River, the Jenkins' Grunter (otherwise known as Western Sooty Grunter or Black Bream) is restricted to main channel sites or larger waterbodies (Figure 4). It is highly regarded as a food fish by local people and

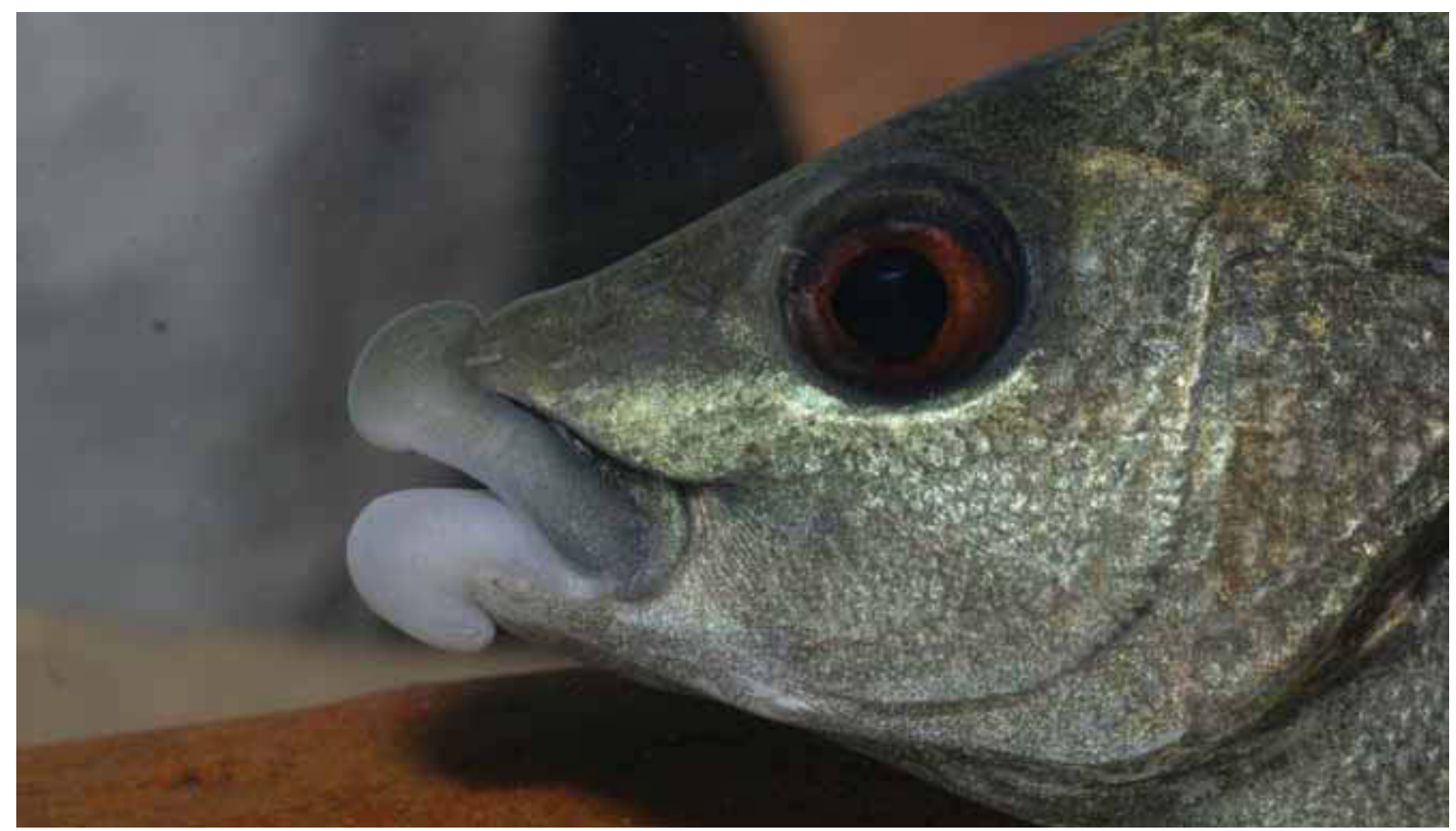

Figure 5 'Blubber lip' condition in Jenkins' Grunter. 
is the most commonly sought-after fish in the area. The species appears to obtain a much larger size in the King Edward than the Fitzroy River or it may be that fishing pressure is less in the King Edward. A relatively large proportion of individuals in the King Edward River have lips enlarged forming large fleshy pads curling posteriorly on both lips (Figure 5), commonly referred to as 'blubber-lips'. Of 61 superficially examined in the Carson River, 19 had obvious 'blubber-lips' while two had minor 'blubber-lips'. The condition is probably genetic but may be related to diet. This condition was previously reported for the species in the Carson River by Hutchins (1977) and has been reported for the species elsewhere by Vari (1978). Vari (1978) also reported this condition in another Kimberley terapontid, i.e. Hannia greenwayi Vari, 1978.

Spangled Perch (Leiopotherapon unicolor (Günther, 1859)) (TERAPONTIDAE)

The Spangled Perch was captured in all but six sites sampled during this study (Figure 4). It was most abundant in the tributary sites and accounted for $\sim 6 \%$ of all captures across all sites. In the tributaries of the King Edward, Morgan and Carson Rivers the species contributed to 10.8, 7 and $13.8 \%$ of the catches, respectively, whereas in the main channel of the upper King Edward and the Carson River they were less abundant contributing to 2.8 and $1.8 \%$, respectively, of the catches in these parts of the catchment (Figures 7 and 8).

\section{Butler's Grunter (Syncomistes butleri Vari, 1978) (TERAPONTIDAE)}

Butler's Grunter was previously only known from rivers east of, and including, the Drysdale River east to the Liverpool River in the Northern Territory (Allen et al. 2002). Thus, its capture within the Carson River represents a westerly range extension for the species (Figure 4). A total of 16 individuals were captured at five sites within the Carson River main channel where they were mainly found under shaded deep river banks.

Long-nose Grunter (Syncomistes trigonicus Vari, 1978) (TERAPONTIDAE)

The Long-nose Grunter is relatively common in the main channel of the upper King Edward River where 241 individuals were captured (Figures 4, 7 and 8). While none were recorded in the tributaries of the King Edward or Carson River, the species was recorded in the Morgan River (4 individuals) and Carson main channel (1 individual).

Empire Gudgeon (Hypseleotris compressa (Krefft, 1864)) (ELEOTRIDAE)

A single Empire Gudgeon was recorded in a small tributary near the mouth of the King Edward River (Figure 4). The species had not previously been recorded from this river, but is widespread throughout northern Australia (Allen et al. 2002).

Slender Gudgeon (Hypseleotris ejuncida Hoese and Allen, 1983) (ELEOTRIDAE)

The Slender Gudgeon was previously only known from a few specimens from Gundarara Creek in the Prince Regent River, West Kimberley (Hoese and Allen 1983). The 21 individuals captured in the Carson River main channel (Figure 4) represent a range extension for the species. At one site all were captured using mask and snorkel and a dip net. Fish were observed suspended almost vertically in the water column amongst fallen leaves and roots of Pandanus.

Kimberley Mogurnda (Mogurnda oligolepis Allen and Jenkins, 1999) (ELEOTRIDAE)

The Kimberley Mogurnda (or False-spotted Gudgeon) was never captured from sites within the main channel of the King Edward or Carson River (Figure 4). It was, however, relatively common in tributary sites, particularly those of the upper King Edward River (Figures 4, 6 and 7). Allen and Leggett (1990) recorded a different species of Mogurnda, the Northern Trout Gudgeon (Mogurnda mogurnda (Richardson, 1844)), from Monger Creek near Kalumburu. Hutchins (1977) also reported seven Northern Trout Gudgeon from Palmoondoora Creek. It is worth noting that the Kimberley Mogurnda was described by Allen and Jenkins in 1999, after the studies by Allen and Leggett (1990) and Hutchins (1977), and they included in their description as paratypes the specimens captured by Hutchins (1977). A number of the Mogurnda captured were retained for examination to ascertain which species they

Table 3 Lateral scale counts of the Kimberley Mogurnda (Mogurnda oligolepis) (overall and from the King Edward River during this study) and for the Northern Trout Gudgeon (Mogurnda mogurnda). Modified from Allen and Jenkins (1999).

\begin{tabular}{lcccccccccccccccccc}
\hline Lateral scale count & $\mathbf{3 0}$ & $\mathbf{3 1}$ & $\mathbf{3 2}$ & $\mathbf{3 3}$ & $\mathbf{3 4}$ & $\mathbf{3 5}$ & $\mathbf{3 6}$ & $\mathbf{3 7}$ & $\mathbf{3 8}$ & $\mathbf{3 9}$ & $\mathbf{4 0}$ & $\mathbf{4 1}$ & $\mathbf{4 2}$ & $\mathbf{4 3}$ & $\mathbf{4 4}$ & $\mathbf{4 5}$ & $\mathbf{4 6}$ & $\mathbf{4 7}$ \\
\hline Northern Trout Gudgeon & & & & & 1 & 5 & 5 & 5 & 2 & 5 & 2 & 2 & 2 & 1 & 1 & 1 & 1 & 2 \\
Kimberley Mogurnda & & 2 & 1 & 9 & 2 & 2 & 9 & 9 & 2 & 1 & & & & & & & \\
King Edward River & & 3 & 8 & 9 & 4 & 5 & 3 & & & & & & & & & & \\
\hline
\end{tabular}


represented. While $M$. mogurnda and $M$. oligolepis have some differences in coloration, with the Kimberley Mogurnda having fewer, and larger, red spots along the base of the anal fin, preserved specimens are best recognised by the number of lateral line scales. The Kimberley Mogurnda generally has fewer lateral line scales but there is some overlap (31-39 in M. oligolepis and 34-47 in M. mogurnda) (see Table 3). From the lateral scale counts of 32 of the 51 Mogurnda captured during this study, all had fewer than 37 scales, but most had less than 34 lateral scales, indicating that they were all likely to be the Kimberley Mogurnda and not the Northern Trout Gudgeon.

Giant Gudgeon (Oxyeleotris selheimi (Steindachner, 1867)) (ELEOTRIDAE)

A single large gudgeon that appeared to be either the Giant Gudgeon (Oxyeleotris selheimi) or the Sleepy Cod (Oxyeleotris lineolata) was found in a tributary of the Carson River (Swider Creek). These species are most easily distinguished by $O$. lineolata lacking dark spots on the anal, pelvic and pectoral fins. While the one captured in the King Edward River was not retained, but had spots on anal fin and based on the geographic range given by Allen et al. (2002) it was almost definitely the former. The Giant Gudgeon, unlike the Sleepy Cod, has a distribution that extends to the western Kimberley. The Sleepy Cod has only been recorded from streams east of, and including, the Ord River (Figure 4).

\section{Flathead Goby (Glossogobius giuris (Hamilton, 1822)) (GOBIIDAE)}

With the exception of four individuals captured near Prap Prap on the upper King Edward River, Flathead Gobies were only caught in the main channel sites sampled in the Carson River or below the waterfall at site 21 on the lower Morgan River (Figure 4).

\section{Habitat associations of the fishes in the King Edward River system}

There were considerable differences in the fish fauna associated with the various sections of the King Edward River system. For example, the number of species captured in the upper King Edward River main channel was low (average of 5.5 species captured/site) compared to the Carson River main channel sites (an average of 12.4 species captured/site) (Figure 6). Similarly, within the Morgan River upstream of site 21, the King Edward River tributaries and the Carson River tributaries, the diversity of fishes was comparatively low, with an average of 3.2, 3.7 and 3.6 species recorded, respectively (Figure 6).

The differences between the fishes in the different

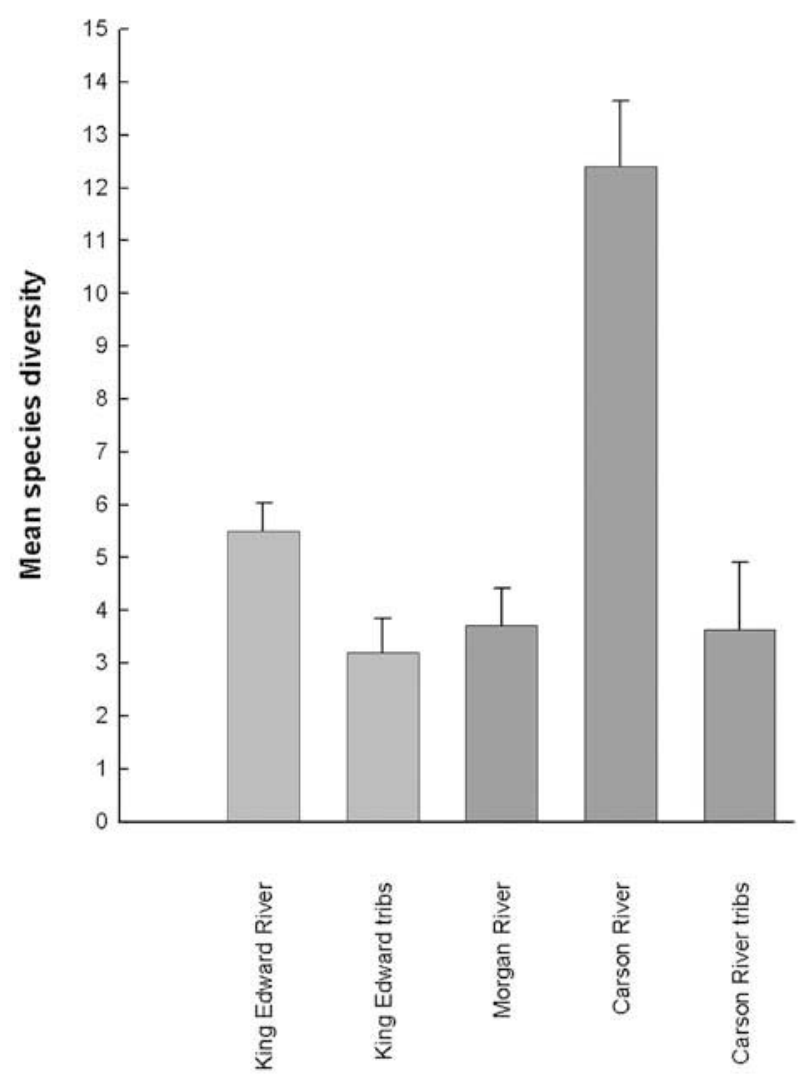

Figure 6 Mean number of fish species captured $( \pm 1 S E)$ in the different regions of the King Edward River system (see also Figure 1).

sections of the catchment can not only be measured in terms of species diversity, but also in the species associations within the various riverine sections. For example, the sites sampled in the King Edward River main channel were dominated by Western Rainbowfish (84.4\% of all fish), Ambassis sp. (6.1\%), Long-nose Grunter (4.3\%), Spangled Perch (2.8\%), Hyrtl's Tandan (1.2\%) and Jenkins' Grunter (1\%), with one Rendahl's Catfish and four Flathead Goby captured at one site (Figure 7). In contrast, within the tributary sites of the King Edward River there were higher relative abundances of the Spangled Perch (10.8\% cf. $2.8 \%$ ) and Hyrtl's Tandan (5.6\% cf. $1.2 \%$ ), but far fewer Jenkins' Grunter (2 individuals cf. 62) and no Long-nose Grunter or Flathead Goby were captured (Figure 7). The Kimberley Mogurnda, while absent from the main channel King Edward sites, was found in six King Edward River tributary sites and contributed to $1.2 \%$ of captures.

The sites sampled in the Carson River and lower Morgan River had far more diverse fish faunas than the upper King Edward River, with not only many of the above species captured, but species recorded also included Barramundi, Silver Cobbler, Lesser 


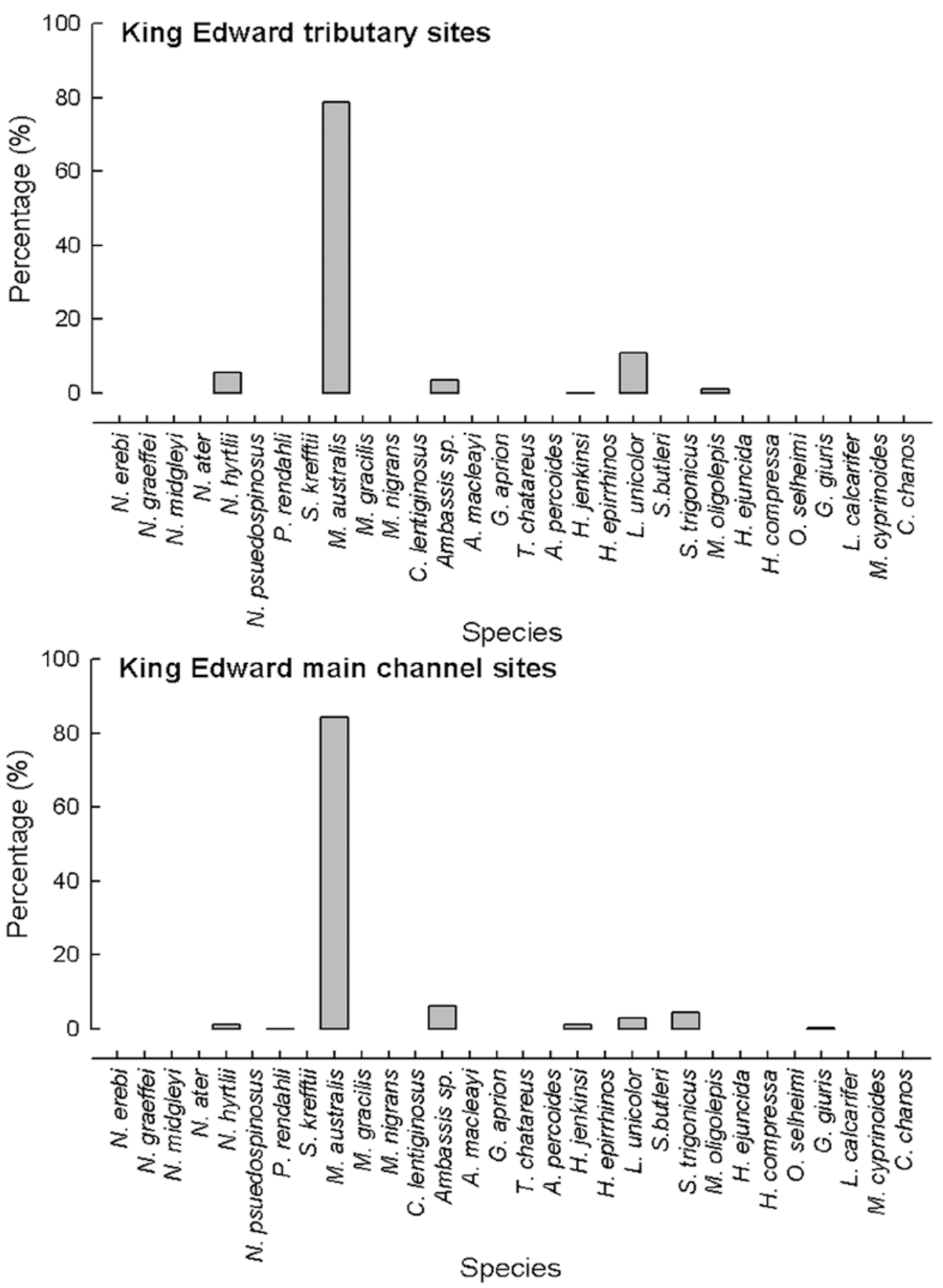

Figure 7 Percentage contributions to the total catch of the different species in the upper King Edward River main channel compared to tributary sites.

Salmon Catfish, Black Catfish, False-spined Catfish, Macleay's Glassfish, Prince Regent Hardyhead, Ox-eye Herring, Seven-spot Archerfish, Flathead Goby, Bony Bream, Butler's Grunter, Barred Grunter, Mouth Almighty, Freshwater Longtom and a restricted species of gudgeon (Slender Gudgeon) (Figure 8). Within these sites the relative contribution of Western Rainbowfish $(20.7 \%)$, Ambassis sp. $(<1 \%)$, Hyrtl's Tandan $(<1 \%)$ and Spangled Perch $(1.8 \%)$ were noticeably lower than within the King Edward River and its tributaries and no Kimberley Mogurnda and only one Longnose Grunter were recorded there. Within the Morgan River and its tributaries upstream of site 21, apart from the Slender Rainbowfish which was recorded at only one site and was found nowhere else during the study, these sites were characterised by a similar suite of species to the King Edward tributaries (Figure 8). The tributaries of the Carson River, which were dominated by Western Rainbowfish (77.2\% of all fish) and Spangled Perch $(13.8 \%)$, were differentiated from other tributary 
Table 4 R-stat values for ANOSIM pairwise comparisons of the fish fauna associated with the different regions of the King Edward River system. Significantly different faunal relationships are represented by: ${ }^{*} \leq 0.5,{ }^{* *} P \leq 0.01$ and ${ }^{* *} P \leq 0.001$.

\begin{tabular}{lcccc}
\hline REGION & King Edward River & King Edward tributary & Morgan River & Carson River \\
\hline King Edward tributary & $0.469^{* *}$ & - & - & - \\
Morgan River & $0.291^{* *}$ & $0.140^{*}$ & - & - \\
Carson River & $0.933^{* * *}$ & $0.945^{* * *}$ & $0.750^{* * *}$ & - \\
Carson tributary & $0.271^{*}$ & $0.207^{*}$ & -0.082 & $0.719^{* * *}$ \\
\hline
\end{tabular}

sites by containing a number of species that are restricted to either these sites or the Carson River main channel (Figure 8).

The above differences in fishes associated with the different regions of the King Edward River system are further highlighted when examining these data using PRIMER. Both MDS and ordination of these data clearly demonstrated similarities (and differences) between the different regions. Both methods separate the Carson River sites from the tributary sites and the King Edward River main channel (Figure 9). The outlying sites on the bottom of the MDS are separated on the basis of each site containing a species that was captured nowhere else in the catchment, i.e. Slender Rainbowfish in the Morgan River tributary (site 18) and the Empire Gudgeon in a Carson River tributary site (site 41).

Analysis of Similarity (ANOSIM) suggested that these major differences in species occurrences throughout the catchment were, in most cases, highly significant $(P<0.01)$ (Table 4$)$. The instance where two regions were considered not to differ in terms of prevailing fish fauna was between the Morgan River and the tributaries of the Carson River. The Carson River main channel however was found to have highly significant differences $(P<$ 0.001) to all other regions sampled (Table 4).

\section{DISCUSSION}

The King Edward River system in the far north of Western Australia's Kimberley region is home to a unique array of fishes. The 27 freshwater fish species is the highest number recorded for any river system in Western Australia and surpasses the known number of freshwater fish species from other Kimberley Rivers, including the much larger Fitzroy and Ord Rivers (see Morgan et al. 2004; Gill et al. 2005). This total however, includes two species of Mogurnda, one of which was recorded during previous studies. These specimens, which were collected by Allen and Leggett (1990) are likely to be the Kimberley Mogurnda which was only recently described by Allen and Jenkins in 1999 (see Table 4). Thus, the King Edward River system is likely to contain at least 26 species of freshwater fish.

The study also resulted in a number of important range extensions. For example, Butler's Grunter was previously only known from rivers east of, and including, the Drysdale River and the finding of Silver Cobbler within the Carson River represents a notable range extension to the west. The extremely cryptic Slender Gudgeon was previously only known from a few specimens from the Prince Regent River and its range has now been extended to the north-east.

Morphological examination of the unidentified glassfish from the King Edward River suggests that is likely to represent an undescribed species. The 10 individuals examined revealed a unique arrangement of head spines, fin rays and relative body measurements (see Table 3). The suborbital, preorbital ridge and hind margin of the preoperculum are all smooth in the glassfish from the King Edward but are spinous in the Northwest Glassfish, which is apparently common throughout the Kimberley (Allen et al. 2002). Furthermore, there are differences in proportional body measurements and generally fewer gill rakers and predorsal scales in the King Edward Ambassis (Table 3).

There were significant differences between the fish fauna associated with the various sections of the King Edward River system. For example, the Carson River main channel was the most diverse in terms of species occurrences, when compared to its tributaries and the tributaries and main channel of the King Edward River. These differences are largely attributed to both the fact that particular species are often associated with either tributaries or larger water bodies and that the upstream migrations of many of the river's species have been hindered by the presence of natural barriers such as rock bars and waterfalls. Thus, it appears that most of the upper King Edward River has been isolated from other rivers, including the Carson River for a long time. Species such as Bony Bream, Lesser Salmon Catfish, Silver Cobbler, Black Catfish, False-spined Catfish, Freshwater Longtom, Prince Regent Hardyhead, Macleay's Glassfish, Mouth Almighty, Seven-spot Archerfish, Barred Grunter and Butler's Grunter are essentially restricted to the 

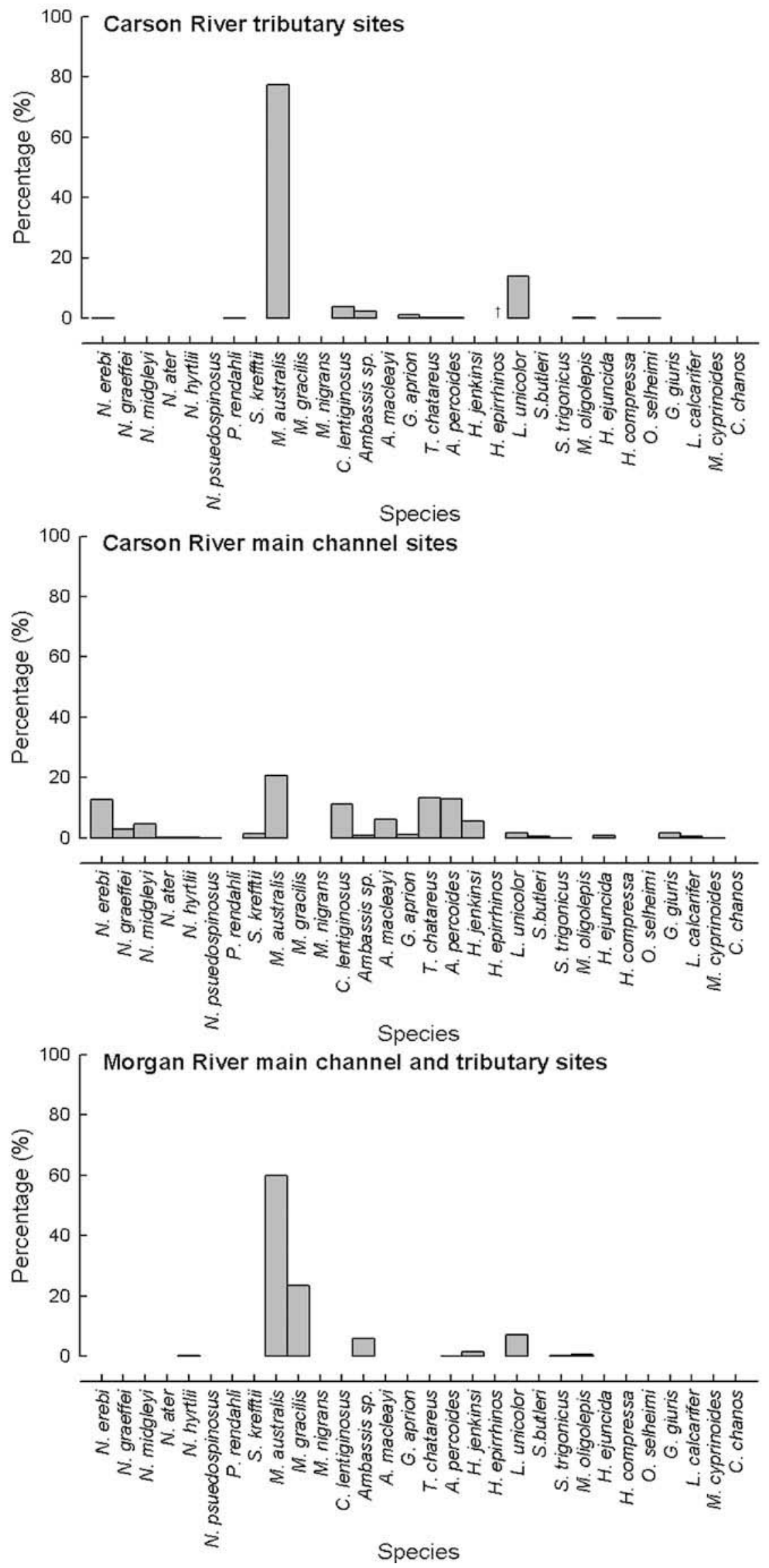

Figure 8 Percentage contributions to the total catch of the different species in the Carson River tributaries, main channel, and the Morgan River main channel and tributaries (upstream of site 21 ). ${ }^{+}$denotes that the species was reported from Palmoondoora Creek by Hutchins (1977). 


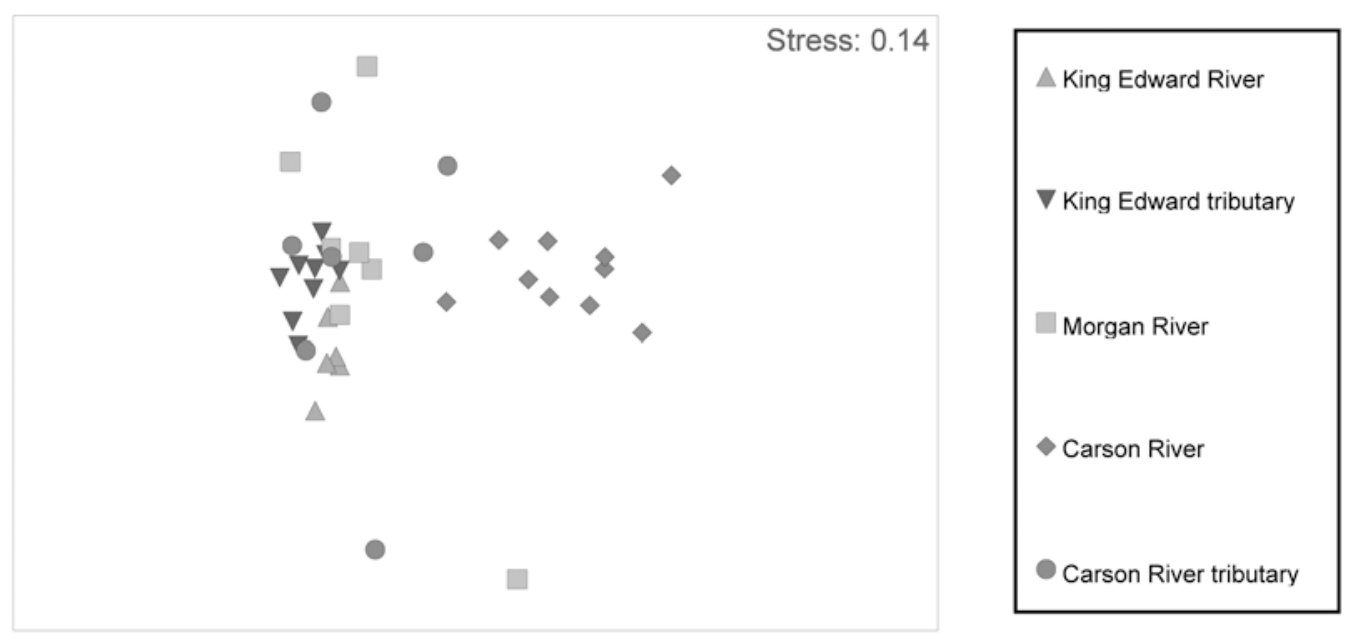

Figure 9 Multidimensional scaling (MDS) plot of the fish species associated with the sites sampled in the King Edward River, the Morgan River and the Carson River and their tributaries (see Figure 1 for site locations).

lower altitude sites on the Carson River (and lower Morgan River and King Edward River) and have never had access to most of the King Edward River. Species such as the Kimberley Mogurnda is mainly restricted to tributary sites while the abundances of Western Rainbowfish and Spangled Perch are much higher in tributaries. Conversely, Jenkins' Grunter are only associated with main channel sites throughout the catchment.

Waterfalls are also seen as limiting the number of migratory marine/estuarine species that enter freshwaters. For example, only two species that must complete their life-cycle in salt water were captured in the King Edward River system. This compares to 14 marine/estuarine species that utilise the freshwaters of the Fitzroy River (Morgan et al. 2004).

It appeared that Jenkins' Grunter population within the King Edward River system were dominated by large fish when compared with the Fitzroy River. Either growth rates are higher due to warmer temperatures experienced in this more northerly river or fishing pressure is far less in the King Edward, or there are underlying genetic differences, or perhaps a combination of each. At popular camping areas the maximum size of Jenkins' Grunter was generally much smaller than in areas that are rarely accessed and thus the species may be susceptible to high fishing pressure. In order to maintain stocks of Jenkins' Grunter and other species that are important food species to the traditional owners of the Kimberley, biological examinations should commence to determine the growth characteristics, length and age at maturity and breeding season of species in the region. Without such knowledge it is difficult to conserve fish stocks and maintain quality fishing opportunities. Thus, both size or bag limits could be applied, and in parts of the system that are important from a conservation perspective, the benefit of establishing Fish Habitat Protection Areas should be addressed.

\section{ACKNOWLEDGEMENTS}

Most importantly I thank the people of the Kimberley, particularly the Traditional Owners at Kalumburu and Prap Prap. In particular I would like to sincerely thank Dolores Cheinmora, Pansy Nulgit, Agnes Charles and Morton Moore, for opening up their country. This project would not have been possible without the financial support of Land and Water Australia. I specifically thank Brendan Edgar from Land and Water Australia for help throughout. Murdoch University also supported the project in terms of vehicles, boats and other equipment and salaries of some staff. Thanks are also extended to the Kimberley Language Resource Centre for support, in particularly I thank Margaret Sefton, Siobhan Casson, Patsy Bedford, June Oscar and Vicki Butters. Thanks to Butch and Robin and the Myers (Theda Station) for providing access to parts of the river on Theda, Simon Visser and Joe Duncan for helping with the field work and all aspects of the trip, Gerry Allen for examining the Slender Gudgeon and Tom Vigilante, Jean Fenton and Hugh Wallace-Smith from the Kimberley Land Council for useful discussions and for support with organising field trips.

\section{REFERENCES}

Allen, G.R. (1975). A preliminary checklist of the freshwater fishes of the Prince Regent River Reserve north-west Kimberley, Western Australia. In: Miles, J.M. and Burbidge, A.A. (eds), A biological survey of the Prince Regent River Reserve North-west Kimberley, Western Australia in August, 1974. Wildlife Research Bulletin of Western Australia 3: 1-116. 
Allen, G.R. (1978). The rainbowfishes of northwestern Australia (Family Melanotaeniidae). Ichthyology 26: 91-102.

Allen, G.R. and Burgess, W.E. (1990). A review of the glassfishes (Chandidae) of Australia and New Guinea. Records of the Western Australian Museum Supplement 34: 139-206.

Allen, G.R. and Feinberg, M.N. (1998). Descriptions of new genus and four new species of freshwater catfishes (Plotosidae) from Australia. Aqua, Journal of Ichthyology and Aquatic Biology 3: 141-156.

Allen, G.R. and Jenkins, A.P. (1999). A review of the Australian freshwater gudgeons, genus Mogurnda (Eleotridae) with descriptions of three new species. Aqua, Journal of Ichthyology and Aquatic Biology 3: 9-18.

Allen, G.R. and Leggett, R. (1990). A collection of freshwater fishes from the Kimberley region of Western Australia. Records of the Western Australian Museum 14: 527-545.

Allen, G.R., Midgley, S.H. and Allen, M. (2002). Field guide to the freshwater fishes of Australia. Western Australia Museum: Perth, Australia.

Eschmeyer, W. (2004). The catalogue of fishes on-line. www. calacademy.org/research/ichthyology/catalog/ fishcatsearch.html [accessed October 2006].

Fowler, H.W. (1905). Some fishes from Borneo. Proceedings of the Academy of Natural Sciences, Philadelphia i(vii): $455-523$.

Gill, H.S., Morgan, D.L., Doupé, R.G. and Rowland, A.J. (2005). The fishes of Lake Kununurra, a highly regulated section of the Ord River in northern Western Australia. Records of the Western Australian Museum 23: 1-6.

Hoese, D.F. and Allen, G.R. (1983). A review of the gudgeon genus Hypseleotris (Pisces: Eleotridae) of Western Australia, with descriptions of three new species. Records of the Western Australian Museum 10: 243-261.

Hutchins, J.B. (1977). The freshwater fish fauna of the Drysdale River National Park North Kimberley,
Western Australia. In: Kabay, E.D. and Burbidge, A.A. (eds), A biological survey of the Drysdale River National Park North Kimberley, Western Australia in August, 1975. Wildlife Research Bulletin of Western Australia 6: 1-133.

Hutchins, J.B. (1981). Freshwater fish fauna of the Mitchell Plateau Area, Kimberley, Western Australia. In: Biological survey of Mitchell Plateau and Admiralty Gulf, Kimberley, Western Australia. Western Australian Museum: Perth, Australia.

MapInfo Corporation (1998). MapInfo professional user's guide. MapInfo Corporation: New York, USA.

Morgan, D.L., Allen, M.G., Bedford, P. and Horstman, M. (2004). Fish fauna of the Fitzroy River in the Kimberley region of Western Australia - including the Bunuba, Gooniyandi, Ngarinyin, Nyikina and Walmajarri Aboriginal names. Records of the Western Australian Museum 22: 147-161.

Morgan, D., Cheinmora, D., Charles, A., Nulgit, P. and Kimberley Language Resource Centre. (2006). Fishes of the King Edward and Carson Rivers with their Belaa and Ngarinyin names. Murdoch University, Kimberley Language Resource Centre, Land and Water Australia Project No. UMU22.

Nelson, J.S. (1994). Fishes of the world. John Wiley and Sons: New York, USA.

Pusey, B., Kennard, M. and Arthington, A. (2004). Freshwater fishes of north-eastern Australia. CSIRO Publishing: Collingwood, Australia.

Vari, R.P. (1978). The terapon perches (Percoidei, Teraponidae). A cladistic analysis and taxonomic revision. Bulletin of the American Museum of Natural History 158: 175-340.

Vigilante, T., Bowman, D.M.J.S., Fisher, R., Russell-Smith, J. and Yates, C. (2004). Contemporary landscape burning patterns in the far North Kimberley region of north-west Australia: human influences and environmental determinants. Journal of Biogeography 31: 1317-1333.

Manuscript received 9 August 2007; accepted 31 December 2008. 